\title{
Appendicectomy, childhood hygiene, Helicobacter pylori status, and risk of inflammatory bowel disease: a case control study
}

\author{
A E Duggan, I Usmani, K R Neal, R F A Logan
}

\begin{abstract}
Aims-To examine the relation between inflammatory bowel disease and appendicectomy, childhood domestic hygiene, and Helicobacter pylori infection.

Methods-Case control study involving 213 patients with ulcerative colitis, 110 with Crohn's disease, and 337 controls having elective surgery.

Results-Nine patients with ulcerative colitis $(4.5 \%)$ reported a previous appendicectomy compared with 57 controls (19\%) (odds ratio (OR) $0.20,95 \%$ confidence interval (CI) $0.1-0.4, \mathrm{p}<0.0001)$. The inverse association was unaffected by excluding operations performed after the age of onset of ulcerative colitis and was stronger for appendicectomy performed before age 20 (OR 0.14). No association with appendicectomy was found for Crohn's disease and no associations with tonsillectomy for either disease. The availability of a fixed hot water supply in early childhood (before age 11) was associated with Crohn's disease (OR for hot water not always versus always available $0.56,95 \%$ CI $0.3-0.9, p=0.02$ ) but not with ulcerative colitis. No other aspect of domestic hygiene before or after age 11 was associated with either Crohn's disease or ulcerative colitis. Although $\boldsymbol{H}$ pylori seroprevalence was positively associated with overcrowding $(p<0.001)$ and the $a b-$ sence of running hot water in childhood it was not associated with the presence of either Crohn's disease or ulcerative colitis. $H$ pylor $i$ seroprevalence was no lower in patients who had been exposed to sulphasalazine than in controls or those not exposed.
\end{abstract}

Conclusions-Our findings confirm the strong inverse association between previous appendicectomy and the development of ulcerative colitis and suggest that the protective effect is greater for appendicectomy performed in childhood.

(Gut 1998;43:494-498)

Keywords: inflammatory bowel disease; appendicectomy; tonsillectomy; childhood hygiene; Helicobacter pylori; sulphasalazine

There is increasing evidence that environmental factors operating early in life can influence the risk of inflammatory bowel disease (IBD) developing many years later. In particular Ekbom has found that infectious and noninfectious events in the perinatal period including measles infection were associated with an increased risk of subsequent IBD ${ }^{1}$ and Gent et al have reported that good domestic hygiene as assessed by the availability of a fixed hot water supply was strongly associated with Crohn's disease. ${ }^{2}$ In addition several recent studies have found that appendicectomy, an operation commonly done in childhood, is associated with a reduced risk of ulcerative colitis. ${ }^{2-7}$ However, in some of these studies the possibility of reverse precedence (ulcerative colitis "protecting" against subsequent appendicectomy) could not be excluded and others have not found a relation. ${ }^{3-11}$

The aims of our case control study were to examine the relation between appendicectomy and ulcerative colitis; to establish its time precedence; and to examine the relation between childhood domestic hygiene and IBD. As a proxy measure of childhood conditions Helicobacter pylori serology was also performed.

\section{Methods}

PATIENTS

The case series consisted of consecutive patients attending the weekly inflammatory bowel disease clinic at University Hospital, Nottingham, during the six month period from October 1993 to April 1994. The hospital records were reviewed to confirm a diagnosis of either ulcerative colitis or Crohn's disease. Patients with indeterminate colitis and patients in whom a diagnosis of ulcerative colitis or Crohn's disease had not been clearly established were excluded. Table 1 summarises the case details of the 213 patients with ulcerative colitis and 110 with Crohn's disease who were included. 
Table 2 Relative risks (RR) for associations with Crohn's disease

\begin{tabular}{|c|c|c|c|c|c|c|c|c|}
\hline & \multicolumn{4}{|c|}{ Exposure before the age of 11} & \multicolumn{4}{|c|}{ Exposure between the age of 11 and 16} \\
\hline & $\begin{array}{l}\text { Cases } \\
(n=l 10)\end{array}$ & $\begin{array}{l}\text { Controls } \\
(n=337)\end{array}$ & $\begin{array}{l}\text { Unadjusted RR } \\
\text { (95\% CI) }\end{array}$ & $\begin{array}{l}\text { Adjusted }{ }^{\star} R R \\
(95 \% C I)\end{array}$ & $\begin{array}{l}\text { Cases } \\
(n=110)\end{array}$ & $\begin{array}{l}\text { Controls } \\
(n=337)\end{array}$ & $\begin{array}{l}\text { Unadjusted RR } \\
\text { (95\% CI) }\end{array}$ & $\begin{array}{l}\text { Adjusted }{ }^{\star} R R \\
(95 \% C I)\end{array}$ \\
\hline \multicolumn{9}{|c|}{ Bed shared with other child } \\
\hline Always or sometimes & 37 & 120 & $0.92(0.6-1.5)$ & $1.00(0.6-1.6)$ & \multicolumn{4}{|c|}{ Variable not ascertained } \\
\hline Never & 69 & 205 & 1.0 & 1.0 & & & & \\
\hline \multicolumn{9}{|c|}{ Bedroom shared with other child } \\
\hline Always or sometimes & 67 & 221 & $0.85(0.5-1.4)$ & $0.89(0.6-1.4)$ & 46 & 172 & $0.65(0.4-1.0)$ & $0.66(0.4-1.1)$ \\
\hline Never & 40 & 112 & 1.0 & 1.0 & 64 & 155 & 1.0 & 1.0 \\
\hline \multicolumn{9}{|l|}{ Running hot water } \\
\hline Never or sometimes & 27 & 125 & $0.55(0.3-0.9)$ & $0.56(0.3-0.9) \dagger$ & 26 & 90 & $0.84(03-1.4)$ & $1.74(0.8-3.8)$ \\
\hline Always & 78 & 198 & 1.0 & 1.0 & 82 & 239 & 1.0 & 1.0 \\
\hline \multicolumn{9}{|l|}{ Fixed bath or shower } \\
\hline Sometimes or never & 34 & 119 & $0.82(0.5-1.4)$ & $1.55(0.8-3.2)$ & 29 & 80 & $1.07(0.64 .7)$ & $1.83(0.9-3.7)$ \\
\hline Always & 74 & 213 & 1.0 & 1.0 & 84 & 247 & 1.0 & 1.0 \\
\hline \multicolumn{9}{|l|}{ Inside toilet } \\
\hline Sometimes or never & 39 & 148 & $0.73(0.5-1.2)$ & $1.23(0.7-2.3)$ & 29 & 106 & $0.76(0.5-1.3)$ & $0.94(0.5-1.8)$ \\
\hline Always & 67 & 186 & 1.0 & 1.0 & 81 & 226 & 1.0 & 1.0 \\
\hline \multicolumn{9}{|c|}{ Home shared with other family } \\
\hline Always or sometimes & 11 & 27 & $1.25(0.6-2.8)$ & $0.96(0.6-1.5)$ & 8 & 22 & $1.11(0.5-2.6)$ & $1.24(03-2.9)$ \\
\hline Never & 97 & 298 & 1.0 & 1.0 & 100 & 306 & 1.0 & 1.0 \\
\hline \multicolumn{9}{|l|}{ Central heating installed } \\
\hline Sometimes or never & 77 & 259 & $0.69(0.4-1.2)$ & $0.91(0.5-1.7)$ & 67 & 224 & $0.74(0.5-1.2)$ & $0.97(0.5-1.8)$ \\
\hline Always & 31 & 72 & 1.0 & 1.0 & 43 & 106 & 1.0 & 1.0 \\
\hline \multicolumn{9}{|l|}{ Parents owned a car } \\
\hline Sometimes or never & 71 & 220 & $0.93(0.6-1.5)$ & $1.37(0.8-2.4)$ & 62 & 200 & $0.83(0.5-1.3)$ & $1.09(0.6-1.9)$ \\
\hline Always & 36 & 104 & 1.0 & 1.0 & 48 & 128 & 1.0 & 1.0 \\
\hline
\end{tabular}

*Adjusted for age, sex and running hot water before the age of 11 .

tAdjusted for age and sex only, $\mathrm{p}=0.02$.

CONTROLS

For each patient an age (within two years) and sex matched control was chosen from patients in hospital for elective surgery. Elective surgery controls were used because the study required a blood specimen to be taken. They also provided some balance for access to and use of hospital services in the case series. Controls were chosen from ward lists of current surgical inpatients with no history of IBD, having elective surgery (gynaecological, orthopaedic, or neurosurgical). Table 1 summarises the demographic details and previous surgical histories of the control series.

QUESTIONNAIRE

Each patient and control was asked to complete a four page questionnaire and to provide a $7 \mathrm{ml}$ clotted blood sample. Patients were approached in the clinic while waiting to be seen and controls were visited on the wards the day before surgery. The questionnaire enquired about previous surgery, in particular appendicectomy, tonsillectomy, cholecystectomy, hysterectomy, and vasectomy, and their age at the time of surgery. Information on childhood domestic circumstances before the age of 11 and after the age of 11 but before leaving home was also sought. Questions included whether they ever shared their home with another family, or ever shared their bed with other children, whether there was running hot water in the home, a plumbed in bath or shower, central heating, or an inside toilet, and whether they attended a nursery school. Answers were on a five point categorical scale of always, often, sometimes, never, or not sure; or a three point scale of always, some of the time, or never. Information on socioeconomic status was also sought, in particular whether their parents ever owned a car, their occupation, and their father's occupation, and the age at which the subject left school. Current and past smoking behaviour was also recorded.
OTHER DATA

In the case series, previous or current use of aminosalicylate drugs was recorded by reference to the notes, or the hospital's IBD patient database. A blood specimen was requested for $H$ pylori serology from both groups at the time they completed the questionnaire. H pylori status was assessed using an enzyme linked immunoassay (ELISA) for anti-H pylori IgG (Porton Cambridge).

\section{STATISTICAL METHODS}

Univariate odds ratios were calculated using Epi-Info V6.02. Odds ratios for all variables were determined after controlling for age and sex by logistic regression with age, sex, and variable all entered into the model using the logistic regression (backwards, likelihood ratio) models to determine independently significant variables. The dependent variables used were ulcerative colitis, Crohn's disease, and $\mathrm{H}$ pylori status.

\section{Results}

No IBD patient approached refused to participate. For organisational reasons blood samples were only obtained from $80 \%$ of IBD patients and $52 \%$ of the control series.

\section{APPENDICECTOMY AND IBD HISTORY}

As table 1 shows, nine of 201 patients with ulcerative colitis $(4.5 \%)$ reported a previous appendicectomy compared with 57 of 295 controls (19\%) and 24 of 102 patients with Crohn's disease $(24 \%)$. The age and sex adjusted odds ratio was 0.20 (95\% confidence interval (CI) $0.1-0.4$ ) for patients with ulcerative colitis having had an appendicectomy and $1.28(95 \%$ CI $0.7-2.3)$ for patients with Crohn's disease compared with controls. There was no relation between having ever smoked and having had an appendicectomy; 63\% (57/90) of those having an appendicectomy 
Table 3 Relative risks (RR) for associations with ulcerative colitis

\begin{tabular}{|c|c|c|c|c|c|c|c|c|}
\hline & \multicolumn{4}{|c|}{ Exposure before the age of 11} & \multicolumn{4}{|c|}{ Exposure between the age of 11 and 16} \\
\hline & $\begin{array}{l}\text { Cases } \\
(n=213)\end{array}$ & $\begin{array}{l}\text { Controls } \\
(n=337)\end{array}$ & $\begin{array}{l}\text { Unadjusted RR } \\
(95 \% \mathrm{CI})\end{array}$ & $\begin{array}{l}\text { Adjusted }{ }^{\star} R R \\
(95 \% C I)\end{array}$ & $\begin{array}{l}\text { Cases } \\
(n=213)\end{array}$ & $\begin{array}{l}\text { Controls } \\
(n=337)\end{array}$ & $\begin{array}{l}\text { Unadjusted RR } \\
(95 \% \mathrm{CI})\end{array}$ & $\begin{array}{l}\text { Adjusted } \\
(95 \% C I)\end{array}$ \\
\hline \multicolumn{9}{|c|}{ Bed shared with other child } \\
\hline Always or sometimes & 84 & 120 & $1.20(0.8-1.7)$ & $1.14(0.8-1.6)$ & \multicolumn{4}{|c|}{ Variable not ascertained } \\
\hline Never & 120 & 205 & 1.0 & 1.0 & & & & \\
\hline \multicolumn{9}{|c|}{ Bedroom shared with other child } \\
\hline Always or sometimes & 130 & 221 & $0.84(0.6-1.2)$ & $0.83(0.6-1.2)$ & 104 & 172 & 0.88 & 0.87 \\
\hline Never & 78 & 112 & 1.0 & 1.0 & 106 & 155 & $(0.6-1.3)$ & $(0.6-1.2)$ \\
\hline \multicolumn{9}{|l|}{ Running hot water } \\
\hline Never or sometimes & 75 & 125 & $0.94(0.6-1.4)$ & $0.82(0.5-1.2)$ & 57 & 90 & $1.02(03-1.5)$ & $0.88(0.6-1.4)$ \\
\hline Always & 126 & 198 & 1.0 & 1.0 & 149 & 239 & 1.0 & 1.0 \\
\hline \multicolumn{9}{|l|}{ Fixed bath or shower } \\
\hline Sometimes or never & 83 & 119 & $1.18(0.8-1.7)$ & $0.97(0.6-1.5)$ & 56 & 80 & $1.07(03-1.6)$ & $0.88(0.6-1.4)$ \\
\hline Always & 126 & 213 & 1.0 & 1.0 & 154 & 247 & 1.0 & 1.0 \\
\hline \multicolumn{9}{|l|}{ Inside toilet } \\
\hline Sometimes or never & 101 & 148 & $1.19(0.8-1.7)$ & $1.06(03-1.6)$ & 71 & 106 & $1.08(03-1.6)$ & $1.10(0.5-2.4)$ \\
\hline Always & 107 & 186 & 1.0 & 1.0 & 140 & 226 & 1.0 & 1.0 \\
\hline \multicolumn{9}{|c|}{ Home shared with other family } \\
\hline Always or sometimes & 17 & 27 & $0.98(0.5-1.9)$ & $0.94(03-1.8)$ & 11 & 22 & $0.77(0.4-1.6)$ & $0.74(03-1.6)$ \\
\hline Never & 192 & 298 & 1.0 & 1.0 & 198 & 306 & 1.0 & 1.0 \\
\hline \multicolumn{9}{|l|}{ Central heating installed } \\
\hline Sometimes or never & 169 & 259 & $1.17(0.8-1.9)$ & $0.96(0.6-1.6)$ & 154 & 224 & $1.32(0.9-1.9)$ & $0.96(0.6-1.6)$ \\
\hline Always & 40 & 72 & 1.0 & 1.0 & 55 & 106 & 1.0 & 1.0 \\
\hline \multicolumn{9}{|l|}{ Parents owned a car } \\
\hline Sometimes or never & 136 & 220 & $0.88(0.6-1.3)$ & $0.68(0.4-1.0)$ & 125 & 200 & $0.93(03-1.3)$ & $1.38(0.9-2.1)$ \\
\hline Always & 73 & 104 & 1.0 & 1.0 & 86 & 128 & 1.0 & 1.0 \\
\hline
\end{tabular}

^Adjusted for age and sex.

reporting having smoked compared with 52\% $(266 / 508)$ of those still having an appendix.

\section{APPENDICECTOMY IN RELATION TO ONSET OF} ULCERATIVE COLITIS

In six patients with ulcerative colitis appendicectomy clearly preceded diagnosis by one year or more; in one patient the time of appendicectomy was close to the time of ulcerative colitis diagnosis; and in two, appendicectomy followed the diagnosis of ulcerative colitis. Using computer generated random numbers 201 age and sex matched controls were then randomly selected from the total control series. Of these 201, 29 reported having had an appendicectomy before the age of diagnosis of the matched patients with ulcerative colitis, giving an odds ratio of 0.18 (95\% CI 0.1-0.4) for appendicectomy performed one year before onset of ulcerative colitis.

AGE OF APPENDICECTOMY AND UC

Three of the 201 patients with ulcerative colitis reported having their appendicectomy before age 20 compared with $29(10 \%)$ of 292 controls (in three controls the age of appendicectomy was not reported); the odds ratio for appendicectomy performed before age 20 was $0.14(95 \%$ CI $0.05-0.4)$

TONSILLECTOMY AND IBD

Reported tonsillectomy showed a weak inverse association with ulcerative colitis (odds ratio $0.81,95 \%$ CI $0.5-1.2$ ) and a weak positive association with Crohn's disease (odds ratio $1.23,95 \%$ CI $0.7-2.1$ ) (see table 1).

Table 4 H pylori status of IBD cases and controls as determined by serology

\begin{tabular}{llllll}
\hline $\begin{array}{l}\text { H pylori status } \\
\text { Controls }\end{array}$ & $\begin{array}{l}\text { Ulcerative } \\
\text { colitis }\end{array}$ & $\begin{array}{l}\text { Crohn's } \\
\text { disease }\end{array}$ & $\begin{array}{l}\text { IBD on } \\
\text { SASP }\end{array}$ & $\begin{array}{l}\text { IBD no } \\
\text { SASP* }\end{array}$ \\
\hline $\begin{array}{lllll}\text { Positive (\%) } \\
\text { Negative }\end{array}$ & $63(36)$ & $59(35)$ & $29(33)$ & $48(32)$ & $13(50)$ \\
Total & 111 & 111 & 58 & 104 & 13 \\
& 174 & 170 & 87 & 152 & 26
\end{tabular}

^No current or previous treatment with sulphasalazine (SASP) or mesalazine.
EARLY DOMESTIC HYGIENE AND IBD As a whole patients with Crohn's disease tended to report coming from "wealthier" homes before age 11 with less bed and bedroom sharing, and more commonly having fixed hot water supplies, inside toilets, and central heating (table 2). After adjustment for age and sex only the availability of running hot water was a significant independent association at the $5 \%$ level. This association was unaffected by inclusion in the model of data on smoking (as current, ex, or never smokers; adjusted relative risk $=0.55)$. After age 11 there was no clear pattern and no statistically significant associations.

For ulcerative colitis there were no statistically significant associations either before or after age 11 with any of the proxy measures of childhood domestic hygiene used (see table 3 ).

\section{H PYLORI SEROLOGY}

Specimens for $H$ pylori serology were obtained from 170 patients with ulcerative colitis, 87 patients with Crohn's disease, and 174 control subjects. Seropositivity showed the expected increase with age with the mean age of the seropositive subjects being 54 years compared with 42 years in those who were seronegative. As well as age, bed sharing before the age of 11 (adjusted odds ratio $1.69,95 \%$ CI 1.1-2.2), and not always having a fixed bath or shower in the home before age 11 (adjusted odds ratio $3.30,95 \%$ CI 2.1-5.1) were associated with being seropositive in multivariate analysis.

As shown in table 4 the prevalence of positive serology was similar in patients and controls. Patients who were taking or had previously taken sulphasalazine had a lower $H$ pylori seroprevalence $(32 \%)$ than patients who had not been exposed to this drug $(50 \%)$ but the difference was not significant at the $5 \%$ level $\left(\chi^{2}=2.6, p=0.11\right)$. 
Table 5 Other published papers reporting an appendicectomy and ulcerative colitis

\begin{tabular}{|c|c|c|c|c|}
\hline \multirow[b]{2}{*}{ Authors } & \multirow[b]{2}{*}{$n$} & \multicolumn{2}{|c|}{ Appendicectomy prevalence (\%) } & \multirow[b]{2}{*}{ Odds ratio $(95 \% \mathrm{CI})$} \\
\hline & & Cases & Controls & \\
\hline Gilat (1987) & 129 & $4(3.0 \%)$ & $26 / 240(11 \%)$ & $0.29(0.10-0.79)$ \\
\hline Gent (1994) & 229 & $11(4.8 \%)$ & $33 / 229(14 \%)$ & $0.3(0.10-0.60)$ \\
\hline Rutgeerts (1994) & 174 & $2(1.1 \%)$ & $41 / 161(25 \%)$ & $0.034(0.008-0.14)$ \\
\hline Wurzelman (1994) & 262 & $3^{\star}(1.1 \%)$ & Not reported & $0.3(0.1-1.1)$ \\
\hline Smithson (1994) & 197 & $7(3.5 \%)$ & $26 / 243(11 \%)$ & $0.20(0.07-0.53)$ \\
\hline \multicolumn{5}{|l|}{ Russel (1997) } \\
\hline Prevalent cases & 232 & $9(3.9 \%)$ & $25 / 232(11 \%)$ & $0.36(0.15-0.80)$ \\
\hline Incident cases & 191 & $12(6.3 \%)$ & $19 / 191(10 \%)$ & $0.56(0.22-1.4)$ \\
\hline Breslin et al (1997) & 177 & $15(8.5 \%)$ & $33 / 189(17 \%)$ & $0.52(0.24-1.12) \dagger$ \\
\hline This study & 201 & $9(4.5 \%)$ & $57 / 295(19 \%)$ & $0.20(0.1-0.4)$ \\
\hline
\end{tabular}

*Only appendicectomy performed before the age of 10 .

$\nmid$ Logistic regression estimate including adjustment for social class.

\section{Discussion}

Our study addressed the hypothesis that the development of inflammatory bowel disease is associated with early childhood domestic hygiene and two events commonly occurring in childhood, namely appendicectomy and the acquisition of $H$ pylori. Our findings confirm the strong inverse association between prior appendicectomy and subsequent ulcerative colitis and also the positive association between the presence of a fixed hot water supply in early childhood and Crohn's disease, as previously reported by Gent et al. ${ }^{2}$ Conversely, we found a positive association between $H$ pylori seroprevalence and the absence of hot water and overcrowding, though no association with either disease or with sulphasalazine and mesalazine usage.

The validity of these findings depends on the absence of bias and confounding. Patients and controls were matched for age and sex and, on analysis, were shown to correspond well for social class. In selecting our patients we chose a prevalent case series of outpatients attending a clinic predominantly for IBD. An incident series might have been more representative of the spectrum of disease but has the attendant problem of unconfirmed or incorrect diagnoses and the slow recruitment rate of uncommon diseases. Furthermore in our clinic the policy is for patients to be reviewed at least annually which reduces the under-representation of patients with inactive or mild disease. Although hospital attendees may be more compliant individuals with an ability to access the hospital system, our hospital control series would be expected to share these characteristics and as elective patients, to be representative of the community. ${ }^{12} 13$ Response or recall bias are unlikely to explain our results. No patients and few controls refused to complete the questionnaire and differential recall of operations between groups is also unlikely. ${ }^{14}{ }^{15}$ Though fewer controls than patients provided a blood specimen, this was primarily due to organisational problems. The appendicectomy rate reported by controls is consistent with other UK studies which have reported rates of $15 \% .{ }^{16}{ }^{17}$ Other data show little variation in appendicectomy rates between the UK, Western Europe, and North America. ${ }^{18}$

As shown in table 5, nine published studies have now found an inverse relation between ulcerative colitis and appendicectomy. Gener- ally the relation has not been as strong as that reported by Rutgeerts and coworkers ${ }^{3}$ and in two studies the relation has not reached statistical significance as can be seen from the $95 \%$ confidence limits. ${ }^{58}$ In only one study, published as an abstract, has no relation been found..$^{10}$ Some of the variation in results can be explained by study size and lack of statistical power as well as the difficulties posed by assessing events in patients and controls before and after diagnosis. Nevertheless most studies have found an odds ratio of $0.2-0.4$ which is as strong as the inverse relation between smoking and ulcerative colitis.

There are two possible explanations for these findings: either the circumstances precipitating appendicitis might protect against developing ulcerative colitis or appendicectomy itself might be protective. The environmental factors involved in appendicitis remain unclear. According to the hypothesis put forward by Barker et al, the rise of appendicitis in Britain in the late nineteenth century reflected improvements in sewage disposal and water supplies in that period, resulting in enteric infections in childhood being avoided or occurring at an older age. ${ }^{19} 20$ The immune system response, because it was more mature, may have been altered and resulted in appendicitis. At present there is little evidence to support the Barker hypothesis and it is difficult to see how the environmental circumstances postulated as promoting appendicitis could also be protective against ulcerative colitis.

The alternative possibility is that removal of the appendix, an organ with no established function, may itself be important. Recent experimental data from a mouse model of colitis lends some biological plausability to this possibility. In experiments using $\mathrm{T}$ cell receptor alpha mutant mice which spontaneously develop IBD, Mizoguchi et al found appendicectomy protected against the development of IBD. ${ }^{21}$ Only $3.3 \%$ of mice appendicectomised at one month developed IBD compared with $80 \%$ of controls; when appendicectomy was performed later (6-12 weeks, more than 12 weeks) more animals developed the disease. Our findings provide some support for this observation as the inverse relation we found was stronger with appendicectomies performed before the age of 20. The stronger inverse relation between early appendicectomy and ulcerative colitis in our study now needs to be examined in data sets larger than ours.

We have been unable to confirm the positive association between tonsillectomy and subsequent Crohn's disease reported by Wurzelman et al. ${ }^{5}$ Nevertheless our findings are consistent with those of several other groups. ${ }^{6}{ }^{8}$ It has also been suggested that tonsillectomy may be associated with ileal Crohn's disease in particular and with risk of colectomy. ${ }^{622}{ }^{23}$ In these studies there was no overall association between Crohn's disease and tonsillectomy and data on site of Crohn's disease were not collected in our study.

A low prevalence of $H$ pylori has previously been found in patients with both Crohn's disease and with ulcerative colitis compared 
with controls and has been associated with previous use of sulphasalazine. ${ }^{2425}$ Sulphasalazine has not been shown to be bactericidal to $H$ pylori either in vitro or in vivo. ${ }^{24}$ We have not confirmed the previous findings of an inverse association between $H$ pylori and IBD or with either past or current sulphasalazine usage. ${ }^{24} 25$ The association between IBD and $H$ pylori found in these studies may reflect selection factors particularly as the numbers involved were relatively small. For this relation to be properly examined it will be necessary to have an incident case series.

The inverse relation between appendicectomy and ulcerative colitis is stronger than any previously noted association with ulcerative colitis. While the aetiology of this association remains unclear it is further evidence that environmental exposures often occurring in childhood influence the risk of developing ulcerative colitis later in life.

1 Ekbom A. Perinatal factors for IBD: a case-control study. Am ₹ Epidemiol 1990;132:1111-19.

2 Gent AE, Hellier MD, Grace RH, et al. Inflammatory bowel Gent AE, Hellier MD, Grace RH, et al. Inflammatory bowel
disease and domestic hygiene in infancy. Lancet 1994;343: disease

3 Rutgeerts P, D'Haens G, Hiele M, et al. Appendectomy protects against ulcerative colitis. Gastroenterology 1994;106: 1251-3

4 Gilat T, Hacohen D, Lilos P, et al. Childhood factors in ulcerative colitis and Crohn's disease. Scand $\mathcal{F}$ Gastroenterol 1987;22:1009-24.

5 Wurzelmann JI, Lyles C, Sandler RS. Childhood infections and the risk of inflammatory bowel disease. Dig Dis $\mathrm{Sc}$ 1994;39:555-60.

6 Smithson JE, Radford-Smith G, Jewell GP. Appendectomy and tonsillectomy in patients with inflammatory bowel disease. $\mathcal{F}$ Clin Gastroenterol 1995;2:283-6.

7 Russel MG, Dorant E, Brummer R-JM, et al, and the South Limburg Inflammatory Bowel Disease Study Group. Appendectomy and the risk of developing ulcerative colitis or Crohn's disease: results of a large case-control study. or Crohn's disease: results of a larg
Gastroenterology 1997;113:377-82.
8 Breslin NP, McDonnell C, O'Morain C. Surgical and smoking history in inflammatory bowel disease: a casecontrol study. Inflammatory Bowel Diseases 1997;3:1-5.

9 Minocha A, Raczkowski CA. Role of appendectomy and tonsillectomy in pathogenesis of ulcerative colitis. Dig Dis Sci $1997 ; 42: 1567-9$.

10 Woods BL, Steinberg EN, Hornung CA, et al. Does appendectomy really protect against ulcerative colitis? [abstract]. Gastroenterology 1995;108:A944.

11 Marion JF, Bodian CA, Janowitz HD. Appendectomy, appendicitis, and inflammatory bowel disease [abstract]. Gastroenterology 1995;108:A870.

12 Wacholder S, Silverman DT, McLaughin JK, et al. Selection of controls in case-control studies. II. Types of controls. Am f Epidemiol 1992;135:1029-41.

13 Olson SH, Kelsey JL, Pearson TA, et al. Characteristics of a hypothetical group of hospital controls for a case-control study. Am $\mathcal{F}$ Epidemiol 1994;139:302-11.

14 Coulter A, McPherson K, Elliott S, et al. Accuracy of recall of surgical histories. Community Med 1985;7:186-9.

15 Paganini-Hill A, Ross RK. Reliability of recall of drug usage and other health related information? Am 7 Epidemiol 1982;116:114-22.

16 Coulter A, McPherson K. Socioeconomic variations in the use of common surgical operations. BMF 1985;291:183-7.

$17 \mathrm{McPherson} \mathrm{K}$, Coulter A, Stratton I. Increasing use of private practice by patients in Oxford requiring common elective surgical operations. BMF 1985;291:797-9.

$18 \mathrm{McPherson} \mathrm{K}$, Wennberg JE, Hovind OB, et al. Small-area variations in the use of common surgical procedures: an international comparison of New England, England, and Norway. N Engl f Med 1982;307:1310-14.

19 Barker DJP, Morris JA, Simmonds SJ, et al. Appendicitis epidemic following introduction of piped water to Anglesey. F Epidemiol Community Health 1988;42:144-8.

20 Barker DJP, Morris JA. Acute appendicitis, bathrooms, and diet in Britain and Ireland. BMF 1988;296:953-8.

21 Mizoguchi A, Mizoguchi E, Chiba C, et al. Role of appendix in the development of inflammatory bowel disease in TCR- $\alpha$ mutant mice. $\mathcal{F}$ Exp Med 1996;184:707-15.

22 Maté-Jimenez J, Correa-Estañ JA, Perez-Miranda M, et al. Tonsillectomy and inflammatory bowel disease location. Eur f Gastroenterol Hepatol 1996;8:1185-8.

23 Breslin N, O'Morain C. Tonsillectomy and inflammatory bowel disease location. Eur f Gastroenterol Hepatol 1997;9: 543-4.

24 El-Omar E, Penman I, Cruikshank G, et al. Low prevalence of Helicobacter pylori in inflammatory bowel disease: association with sulphasalazine. Gut 1994;36:1385-8.

25 Halme L, Rautelin H, Leidenius M, et al. Inverse correlation between Helicobacter pylori infection and inflammatory bowel disease. 7 Clin Pathol 1996;49:65-7. 